$$
\begin{aligned}
& \text { 高 } \mathrm{Cr} \text { フェライト系耐熱鋼溶接継手部のクリープに伴う } \\
& \text { 水素放出特性の変化 }
\end{aligned}
$$

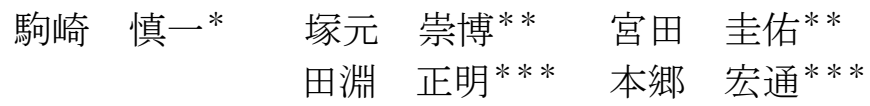

\title{
Change in Hydrogen Desorption Characteristic of Welded Joint of High Cr Ferritic Steel Due to Creep
}

by

\author{
Shin-ichi Komazaki*, Takahiro Tsukamoto**, Keisuke MiYata** \\ Masaaki $\mathrm{TABUCHI}^{* * *}$ and Hiromichi $\mathrm{HONGO}^{* * *}$
}

\begin{abstract}
In order to investigate the applicability of hydrogen as a tracer for detecting Type IV creep damage, the hydrogen thermal desorption analysis (TDA) was applied to the small plate-type specimen $(10 \times 6 \times 0.5 \mathrm{~mm})$ containing weld metal (WM), heat affected zone (HAZ) and base metal (BM). The specimens were taken from the large cross weld specimens of ASME Gr.122 steel with various degrees of creep damage. Hydrogen charging was carried out by means of cathodic electrolysis, and the hydrogen-charged specimen was subjected to the TDA for measuring the hydrogen evolution curve. Experimental results revealed that the hydrogen desorption characteristic was changed depending on not only the degree of creep damage but also the distance from outer surface. The amount of desorbed hydrogen, $C_{\mathrm{H}}$, increased with consuming creep life from the early stage of creep damage, and this increase was more pronounced at the distances of around 5.5 and $20 \mathrm{~mm}$ from the surface. This result indicated that the creep damage was preferentially initiated and accumulated at those regions. From the individual analyses of WM, HAZ and BM specimens, it was also found that the increase in $C_{\mathrm{H}}$ was caused principally by the creep damage accumulated in HAZ, especially, FGHAZ and ICHAZ. Additionally, the change in hydrogen thermal desorption characteristic was well correlated with the area fraction of creep voids and the small punch creep strength.
\end{abstract}

\section{Key words:}

Hydrogen, Thermal desorption analysis, High Cr ferritic steel, Gr.122 steel welded joint, Heat affected zone, Type IV creep damage, Small punch creep test

\section{1 緒言}

高温強度や耐食性に優れた高 $\mathrm{Cr}$ フェライト系耐熱鋼 1) が火力発電プラント等の高温機器に広く利用されている が，本鋼種の溶接継手部での不具合が世界的な問題とな っている.これは, 溶接時の入熱により形成される溶接熱 影響部（HAZ: Heat Affected Zone）においてボイドなどの 損傷が早期に発生し破壊に至る現象であり，Type IV 損傷 2)-6) として知られている. プラントにおける本鋼種使用部 位の健全性の確保と破壊の未然防止には溶接部を主体と した余寿命診断技術の開発が不可欠である.

水素昇温脱離分析法は，水素チャージした試料を昇温 速度一定のもとで加熱し, 計測される水素放出曲線から 水素の存在状態を評価する技術である7)-10). 水素がトラッ プされる久陥と水素の結合エネルギーは欠陥の種類によ
って異なるため, 材料内部の損傷状態に応じて水素放出 特性が変化する. 著者 ${ }^{11), 22}$ らは, Gr.91 鋼のクリープに伴 う水素放出特性の変化を調查し, 水素チャージ後の水素 放出量がクリープ損傷の進行に伴い増加することを明ら かにした．このような水素放出特性の変化はクリープに よる欠陥 (空孔クラスターやボイドなど) の生成・成長挙 動を反映していた．また, 前報 ${ }^{5}$ では, Gr.122 鋼溶接継手 のクリープ損傷材より採取した試料の水素放出特性を調 查し, HAZ を含んだ溶接継手部の水素放出特性の変化が 母材や溶接金属に比べより顕著であることを報告した。 得られた結果は, Type IV 損傷が HAZ にて発生・蓄積す るという従来の知見と合致していた。

本研究では, Type IV 損傷評価への水素昇温脱離分析法 の適用性についてより詳細に検討した. 供試体は, ヒート

$\dagger$ 原稿受理 平成30年7月12日 Received July 12, $2018 @ 2019$ The Society of Materials Science, Japan

* 正 会 員 鹿児島大学大学院理工学研究科 ₹890-0065 鹿児島市郡元 Graduate School of Science and Engineering, Kagoshima University, Korimoto, Kagoshima, 890-0065.

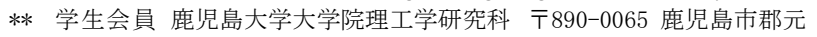
Graduate School of Science and Engineering, Kagoshima University, Korimoto, Kagoshima, 890-0065.

*** 正 会 員 (独)物質・材料研究機構 $\bar{\top} 305-0047$ つくば市千現 National Inst. for Material Sci. Sengen, Tsukuba, 305-0047. 
Table 1 Chemical composition of Gr.122 steel (mass \%).

\begin{tabular}{|c|c|c|c|c|c|c|c|c|c|c|c|c|c|c|c|}
\hline $\mathrm{C}$ & $\mathrm{Si}$ & $\mathrm{Mn}$ & $\mathrm{P}$ & $\mathrm{S}$ & $\mathrm{Cu}$ & $\mathrm{Ni}$ & $\mathrm{Cr}$ & $\mathrm{W}$ & $\mathrm{Mo}$ & $\mathrm{V}$ & $\mathrm{Nb}$ & $\mathrm{Al}$ & $\mathrm{N}$ & $\mathrm{B}$ \\
\hline 0.11 & 0.28 & 0.62 & 0.015 & 0.002 & 0.98 & 0.39 & 10.54 & 1.82 & 0.32 & 0.19 & 0.05 & 0.001 & 0.063 & 0.003 \\
\hline
\end{tabular}

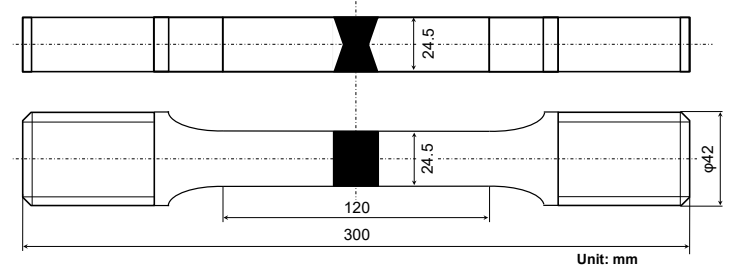

Fig. 1 Large cross weld specimen Gr.122 steel.
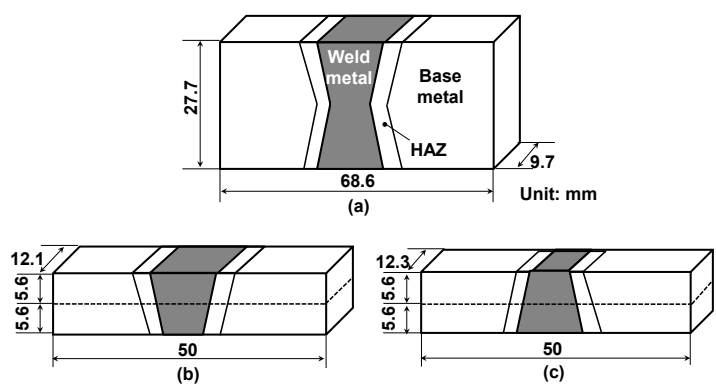

Fig. 2 Welded joint parts removed from creep specimen. (a) As-received, (b) $20 \%, 46 \%$ and $92 \%$ damaged, (c) $82 \%$ damaged.

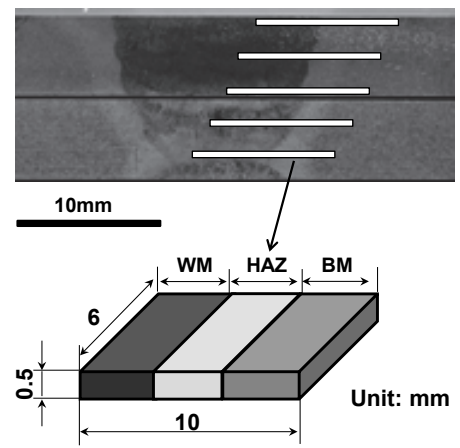

Fig. 3 Sampling portions and geometry of small rectangular specimen.

や溶接施工法, 損傷付与条件は異なるものの, 前報と同様 に Gr.122 鋼溶接継手材を用いた．損傷度の異なる複数の クリープ中断材を対象に, 表面からの距離が種々異なる 箇所より採取した微小サンプルの水素放出曲線を測定し, 板厚方向の詳細な水素放出特性の分布を調べた. また, 水 素放出特性変化の機序解明の一環として, HAZ のみなら ず, HAZ 内の局所領域の水素放出特性の測定を試みた. さらには, 水素放出特性変化と硬さやボイド面積率, スモ ールパンチクリープ破断試験結果との関係についても調 査した。

\section{2 供試材および実験方法}

\section{$2 \cdot 1$ 供試材}

供試材として, 肉厚 $30 \mathrm{~mm}$ の Gr.122 鋼板を用いた. そ の化学組成を Table 1 に示す. 本鋼を用いて H 開先の溶接
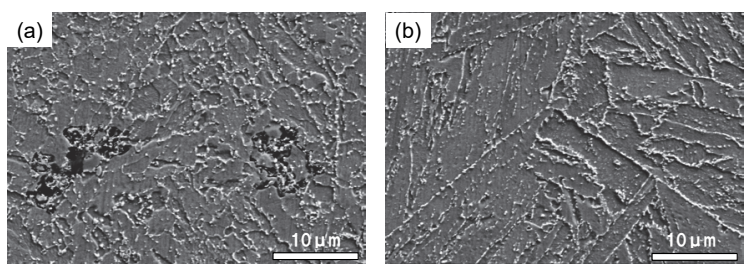

Fig. 4 Examples of microstructure. (a) $1.5 \mathrm{~mm}$ and (b) $5.0 \mathrm{~mm}$ distances from fusion boundary.

継手をガスタングステンアーク溶接により作製した。 $750^{\circ} \mathrm{C} / 75 \mathrm{~min}$ の溶接後熱処理の後, 開先のほぼ全積層を含 む幅 $24.5 \mathrm{~mm}$, 厚さ $24.5 \mathrm{~mm}$, 平行部長さ $120 \mathrm{~mm}$ の大型 平行板溶接継手試験片（Fig. 1）2)を製作した. 同試験片を 用いて, 温度 $600^{\circ} \mathrm{C}$, 応力 $100 \mathrm{MPa}$ の条件でクリープ試験 を行い，破断時間（16340h）の 20\%(3268h), 46\%（7540 h)，82\%（13740h）および92\%（15080h）でそれぞれ試 験を途中止めしてクリープ中断材を作製した. 各中断材 の平行部より切り出したブロック（Fig. 2）を対象に, 後 述するマイクロビッカース硬さ計測や水素昇温脱離分析 を実施した。なお，残材の都合上，20\%，46\%および $92 \%$ 損傷材は平行部の外表面側半分, $82 \%$ 損傷材は内表面側半 分を試験体とした.

\section{$2 \cdot 2$ ビッカース硬さ計測}

マイクロビッカース硬度計を用いて, 荷重 $4.9 \mathrm{~N}$, 保持 時間 $10 \mathrm{~s}$ の条件で受取りまま材および各損傷材の HAZ 近 傍の硬さ分布を計測した. 硬さは, 溶融境界を基準として $0.25 \mathrm{~mm}$ 間隔で測定した.

\section{$2 \cdot 3$ 水素昇温脱離分析}

水素昇温脱離分析用試料として, 母材 (BM: Base Metal), 熱影響部（HAZ）および溶接金属（WM: Weld Metal）のす べてを含む $10 \times 6 \times 0.5 \mathrm{t} \mathrm{mm}$ の小型長方形状試験片を用い た（Fig. 3). 試料は，溶接金属の幅が $3.5 \mathrm{~mm}$ になるよう に統一し切り出した。受取りまま材については外表面側 から内表面側にかけての 10 力所から，20\%，46\%, 92\%の 各損傷材については外表面側から肉厚中央にかけての 5 力所から, 82\%損傷材については内表面側から肉厚中央に 向けての 5 カ所から, ワイヤー放電加工によって試料を 切り出した. 最終表面仕上げは\#2400 とし, 湿式研磨によ り板厚を $0.5 \pm 0.005 \mathrm{~mm}$ に調整した.

水素チャージは, 触媒毒として $\mathrm{NH}_{4} \mathrm{SCN}$ を $0.5 \mathrm{mass} \%$ 添 加した $0.1 \mathrm{~mol} / \mathrm{L} \mathrm{NaOH}$ 水溶液中 $\left(30^{\circ} \mathrm{C}\right)$ にて, 電流密度 : $5 \mathrm{~mA} / \mathrm{cm}^{2}$, チャージ時間 : $4 \mathrm{~h}$ の条件下にて陰極電解法に よって行った. 水素チャージ後, 昇温加熱機構付きガスク ロマトグラフを用いて水素放出曲線を測定した. 室温で も水素が逃散してしまうことから，チャージ終了から分 析開始までの時間を 5 min と統一した. キャリアガスとし てアルゴンを用い, 昇温速度 : $100^{\circ} \mathrm{C} / \mathrm{h}$, 測定温度範囲 : 
(a) As-received

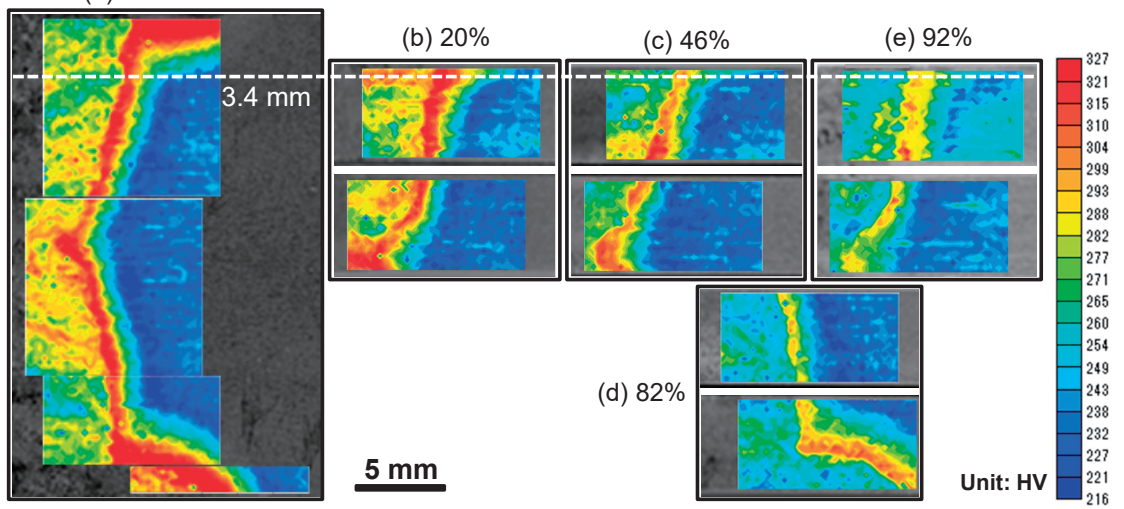

Fig. 5 Hardness mapping at around HAZ.

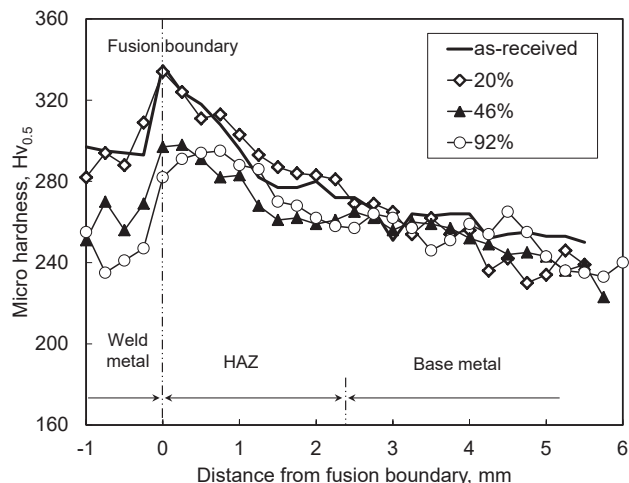

Fig. 6 Change in hardness distribution at $3.4 \mathrm{~mm}$ distance from outer surface.

室温〜室温 $+250^{\circ} \mathrm{C}$ のと, 放出された水素の濃度を $5 \mathrm{~min}$ に一度の間隔で測定した。

\section{3 結果および考察}

\section{$3 \cdot 1$ クリープに伴うミクロ組織と硬さの変化}

92\%損傷材において, 溶融境界から熱影響部へ向かって $1.5 \mathrm{~mm}, 5.0 \mathrm{~mm}$ の箇所でのミクロ組織の様子を Fig. 4 に 示す. 溶融境界から $1.5 \mathrm{~mm}$ の箇所（Fig. 4(a)）では，ラス マルテンサイト組織は認められず細粒組織が観察された。 また，同図からわかるように，多数のボイドが発生してい た。他方，溶融境界から $5.0 \mathrm{~mm}$ の箇所（Fig. 4(b)）は母材 に対応しており，明瞭なラス組織を呈していた. 各損傷材 で得られた HAZ 近傍の硬さマップをまとめたものを Fig. 5 に示す. 領域によって変化の程度は幾分異なっていたが, 全体的には寿命消費に伴い硬さが低下寸る傾向が観察さ れた．外表面からの距離が $3.4 \mathrm{~mm}$ の位置での受取りまま 材，20\%，46\%，92\%損傷材の HAZ 近傍での硬さ分布を Fig. 6 に示す。同図からわかるように，溶融境界近傍で硬 さがもっとも高くなっている，受取りまま材と $20 \%$ 損傷 材の硬さ分布には大きな差異は認められないが, $20 \%$ 損傷 材の母材は幾分低下している. 寿命比が $46 \%$ になると溶 接金属と HAZ における硬さが減少しているのがわかる. さらに，寿命比が $92 \%$ に達すると，HAZ の硬さにはあま り大きな変化は認められないものの, 溶接金属の軟化が
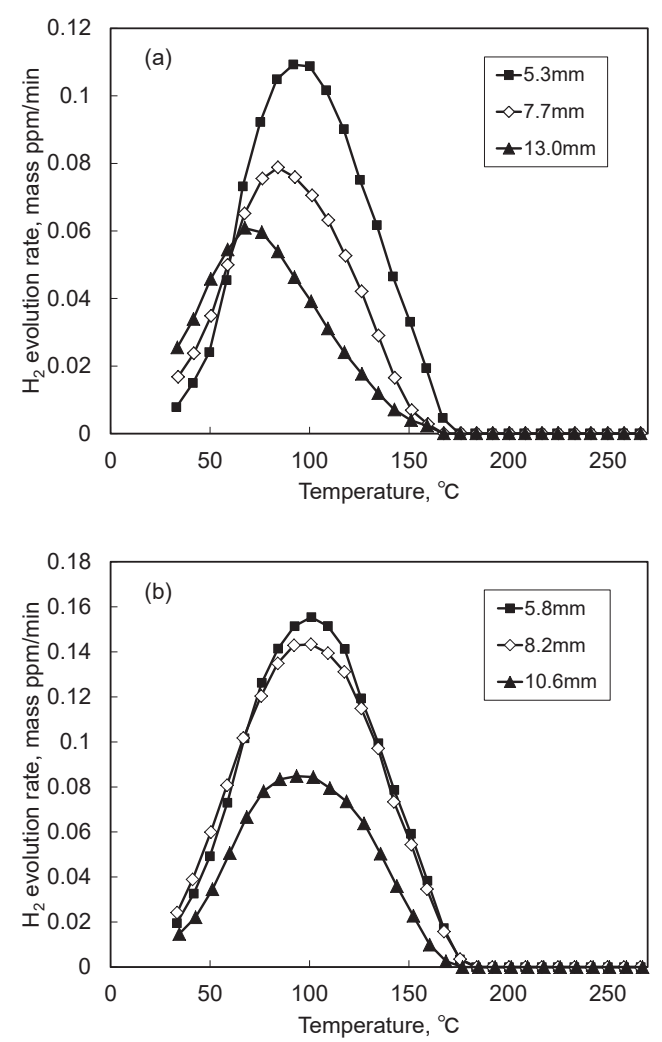

Fig. 7 Examples of hydrogen evolution curves of interrupted creep specimens. (a) $46 \%$, (b) $92 \%$.

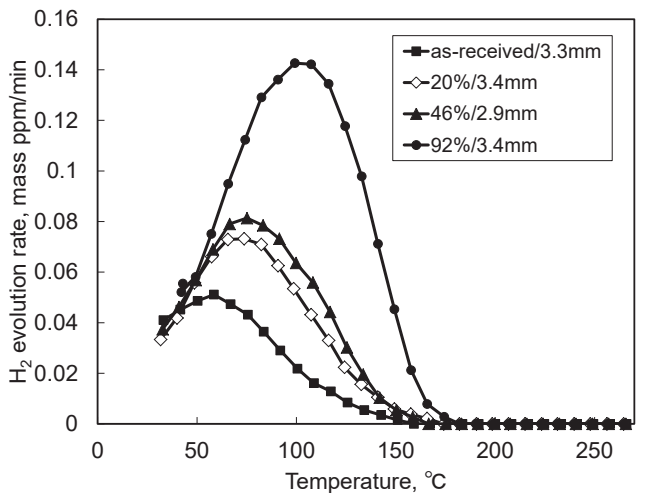

Fig. 8 Change in hydrogen evolution curve with creep. 


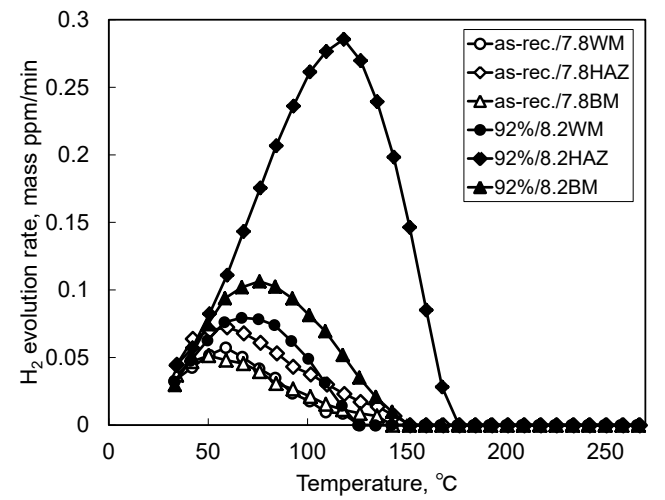

Fig. 9 Change in hydrogen evolution curve of separated specimen of as-received and $92 \%$ damaged.

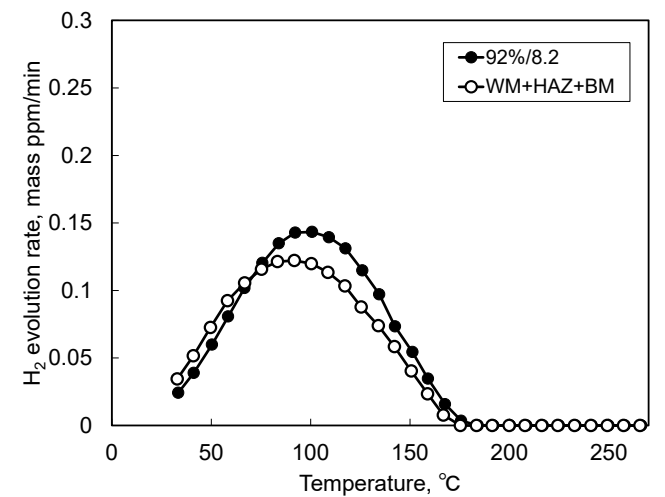

Fig. 10 Hydrogen evolution curves of $92 \%$ damaged.

さらに顕著になる.なお, 圧痕のサイズ (対角線長さ) は, 例えば，母材部では $60 \mu \mathrm{m}$ 程度であった。

\section{$3 \cdot 2$ クリープに伴う水素放出特性の変化}

水素放出曲線の例として，46\%，92\%損傷材で計測され たものを Fig. 7 に示す. 46\%損傷材（Fig. 7(a)）は外表面か らの距離が 5.3，7.7，13.0 mm の位置から採取した試料の 水素放出曲線であり，92\%損傷材（Fig. 7(b)）については 5.8，8.2，10.6 mm の結果となっている．程度の差はある ものの，両損傷材ともに 5 6 mm 近傍のピーク值が一番 高く，10〜13 mm のそれがもっとも低くなっている．ま た，92\%損傷材のピーク温度が $100^{\circ} \mathrm{C}$ 近傍とほぼ一定であ るのに対して, 46\%損傷材については外表面に近づくにつ れてピークが高温側にシフトしている．ピーク温度が高 温側にシフトする理由の詳細は未だ明らかではないが, 欠陥の数が増えるとともにそれらのサイズや形状が変わ り，水素との結合形態（結合エネルギー）が変化するのが その要因であると考えられる.

各損傷材の外表面にもっとも近い位置（2.9〜3.4 mm) から採取した試料で計測された水素放出曲線を示した ものが Fig. 8 である．同図からわかるように，寿命消費 に伴い水素放出速度のピーク高さが上昇し，ピーク温度 も高温側へシフトしている。受取りまま材のピーク高さ が $0.05 \mathrm{mass} \mathrm{ppm} / \mathrm{min}$ であったのに対し，92\%損傷材にな ると $0.14 \mathrm{mass} \mathrm{ppm} / \mathrm{min}$ と 3 倍程度にまで顕著に増加し

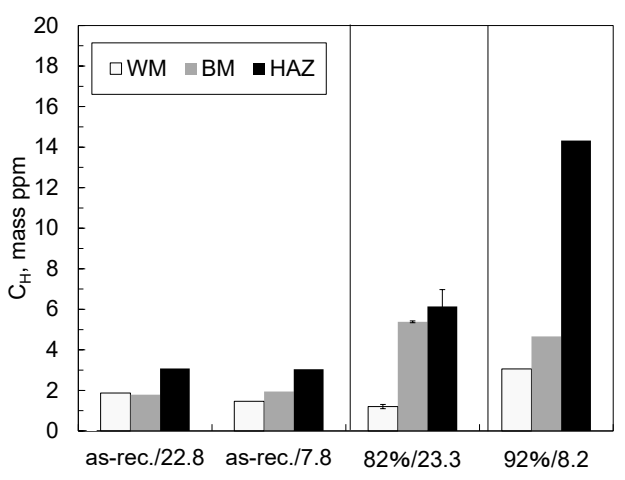

Fig. $11 C_{\mathrm{H}}$ measured on WM, BM and HAZ of as-received, $82 \%$ and $92 \%$ damaged.

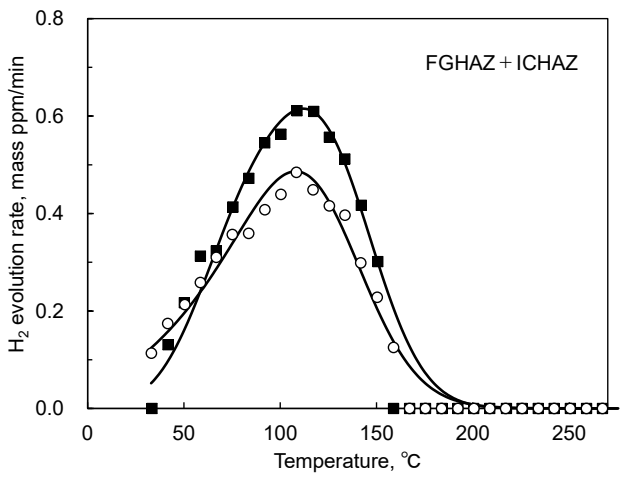

Fig. 12 Hydrogen evolution curves of FGHAZ+ICHAZ.

た. 前報 5) と比較すると，ヒートは異なるものの受取り まま材のピーク高さは前報の值（0.055 mass ppm/min）と 同じであった。しかし，92\%損傷材のピーク高さは前報 における $93 \%$ 損傷材のそれ（0.22 mass ppm $/ \mathrm{min} ）$ に比べ 幾分減少する結果となった。これは，前報とは開先形状 や試験片形状，試験条件が異なり，HAZ 内における欠陥 の性状 (空孔クラスターやボイドのサイズ, 形状, 分布, 発生個所など）が必ずしも同じではないためだと考えら れた。

水素放出特性変化の機序を明らかにするため, 溶接金 属, HAZ, 母材の各微小領域の水素放出曲線の測定を行っ た. 具体的には, $92 \%$ 損傷材の外表面下 $8.2 \mathrm{~mm}, 82 \%$ 損傷 材の外表面下 $22.8 \mathrm{~mm}$ より採取した試料に加え, 受取り まま材の同一位置から切り出したものを対象に，溶接金 属, HAZ, 母材をカッターによって切断しそれぞれ前述し た水素昇温脱離分析に供した。得られた結果の一例とし て，92\%損傷材と受取りまま材の外表面下 $8 \mathrm{~mm}$ 近傍の試 料で計測された水素放出曲線を Fig. 9 に示す. 受取りまま

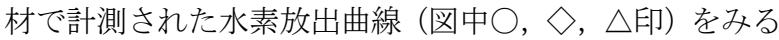
と, HAZ のピークが幾分高くなっているが，溶接金属と 母材の間にはピーク温度やピーク高さにほとんど差異は ない. 他方, 92\%損傷材 (図中 $\boldsymbol{O}$, $\boldsymbol{\Delta}$ 印) においては, 受取りまま材と比較して溶接金属, HAZ, 母材のすべてて ピーク温度とピーク高さが増加しており，HAZ ではその 変化が極めて顕著である. 92\%損傷材の各微小領域の水素 


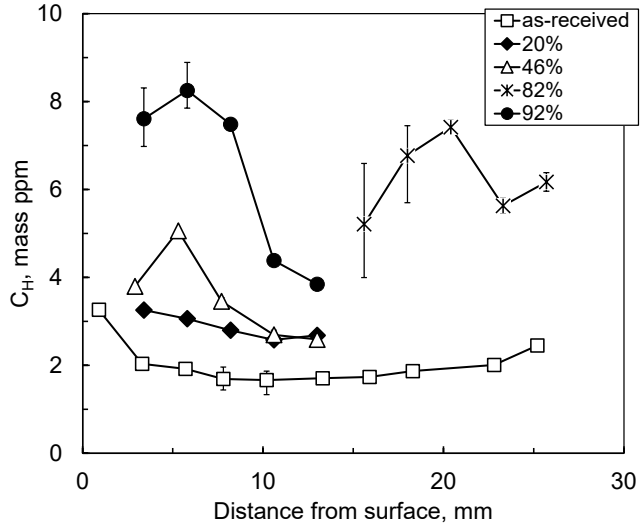

Fig. $13 C_{\mathrm{H}}$ plotted as a function of distance from outer surface.

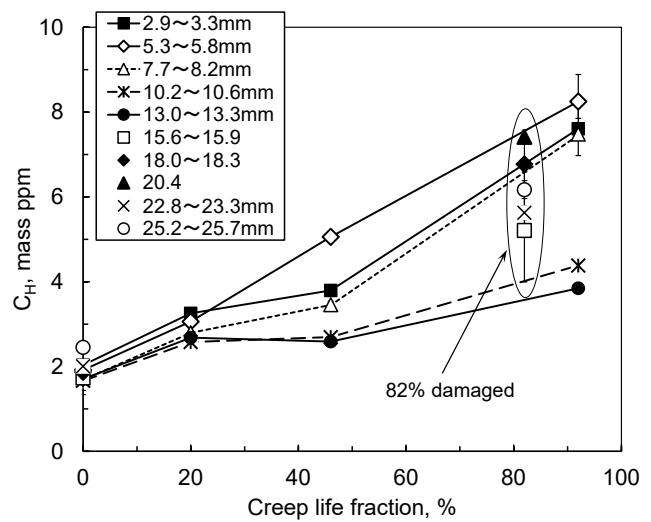

Fig. $14 \mathrm{CH}_{\mathrm{H}}$ plotted as a function of creep life fraction.

放出曲線の和 (図中○印) を切断前に溶接継手全体で計測 された水素放出曲線 (図中@印) と併せて Fig. 10 に示寸. 両曲線は比較的良く一致しており，溶接金属，HAZ，母材 の各微小領域の水素放出曲線を足し合わせたものが溶接 継手全体で計測される水素放出曲線になることを改めて 確認することができた。

水素放出曲線下の面積から計測中に放出された水素の 量 $C_{\mathrm{H}}$ を算出した. 各微小領域で計測された水素放出量 $C_{\mathrm{H}}$ をまとめたものが Fig. 11 である. 受取りまま材の $C_{\mathrm{H}}$ は採 取位置による差異はなく, HAZ の $C_{\mathrm{H}}$ が 3 mass ppm と母 材や溶接金属の $1.5 \sim 2$ mass ppm に比べわずかに高くなっ ている。一方，82\%損傷材においては，溶接金属では受取 りまま材と比べほとんど $C_{\mathrm{H}}$ に差はないが，母材と HAZ では $C_{\mathrm{H}}$ が 6 mass ppm 程度まで増加している。これは, 82\%損傷材では HAZ と母材に損傷が発生・蓄積している ことを示唆している.さらに, 寿命比が破断直前の $92 \%$ に なると, HAZ の $C_{\mathrm{H}}$ は受取りまま材の 5 倍程度にまで増 加している.

HAZ におけるこのような水素放出特性の変化をもう少 し詳しく理解するため, HAZ 内での水素放出特性分布の 特定を試みた。一般に, 溶接時の最大加熱温度に応じて, HAZ は溶融境界から母材に向かって粗粒域（CGHAZ: Coarsened Grain HAZ), 細粒域（FGHAZ: Fine Grain HAZ）
およびインタークリティカル域(ICHAZ: Inter-Critical HAZ) とミクロ組織の異なる 3 つの局所領域に分類される. 各 領域は連続的に変化しておりその幅も極めて小さいこと から，それぞれの局所領域から正確に試料を切り出すの は難しく, 特に FGHAZ と ICHAZ の境界の識別が困難で あったそそこで，FGHAZ と ICHAZ の両局所領域を含ん だ試料を HAZ からさらに切り出し, その水素放出曲線を 計測した. $92 \%$ 損傷材の外表面下 $8 \mathrm{~mm}$ 近傍の局所領域試 料で計測された水素放出曲線を Fig. 12 に示す. 同一試料 を用いて 2 回測定した結果が同図には示されている。ピ 一ク高さは $0.5 \sim 0.6 \mathrm{mass} \mathrm{ppm} / \mathrm{min}$ 程度となっており, Fig. 9 中の HAZ 全体（CGHAZ + FGHAZ + ICHAZ）の水素放 出曲線（図中印）のピーク高さ $0.3 \mathrm{mass} \mathrm{ppm} / \mathrm{min}$ に比心゙ 2 倍程度高くなっている。これは, HAZ の中でも特に FGHAZ や ICHAZ に損傷がより多く発生・蓄積している ことを意味している.

\section{$3 \cdot 3$ 水素放出特性の変化とクリープ損傷}

前節で述べたように, 水素放出特性は寿命比のみなら ず，外表面からの距離にも依存し異なっていた．各試料 で計測された水素放出量 $C_{\mathrm{H}}$ を外表面からの距離に対し てプロットしたものを Fig. 13 に示す. 受取りまま材の $C_{\mathrm{H}}$ は，もっとも外表面に近い位置で比較的高い值 $(3.3$ mass ppm）になっているものの, 試験片内部では 1.7〜2 mass ppm とほぼ一定である. $20 \%$ 損傷材では, 測定対象 域において受取りまま材に比べ 1 mass ppm 程度 $C_{\mathrm{H}}$ が増

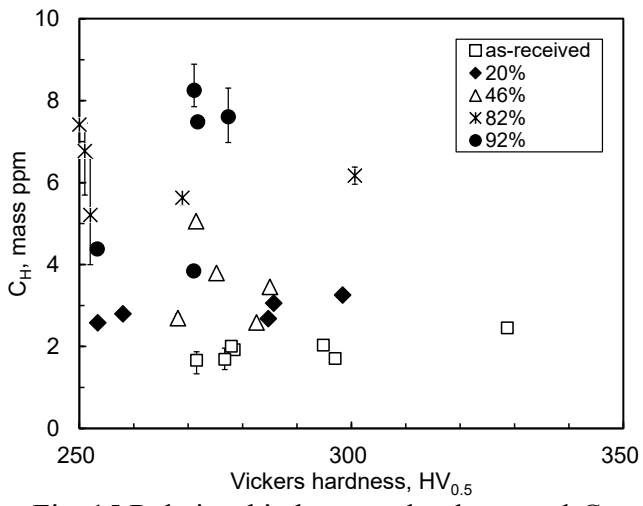

Fig. 15 Relationship between hardness and $C_{\mathrm{H}}$.

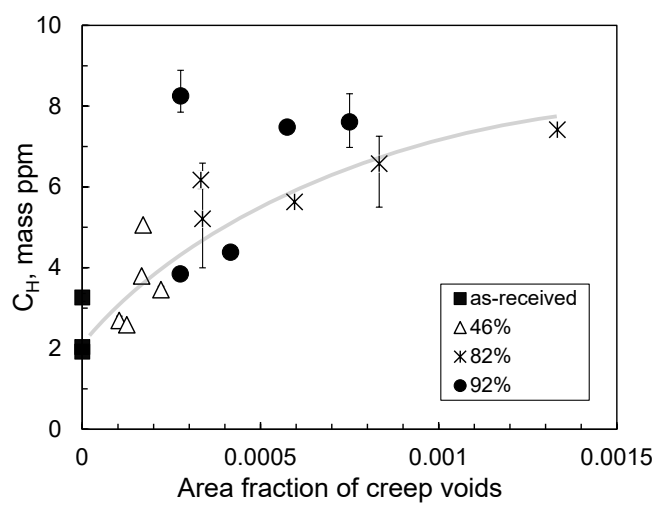

Fig. $16 C_{\mathrm{H}}$ plotted against area fraction of creep voids. 


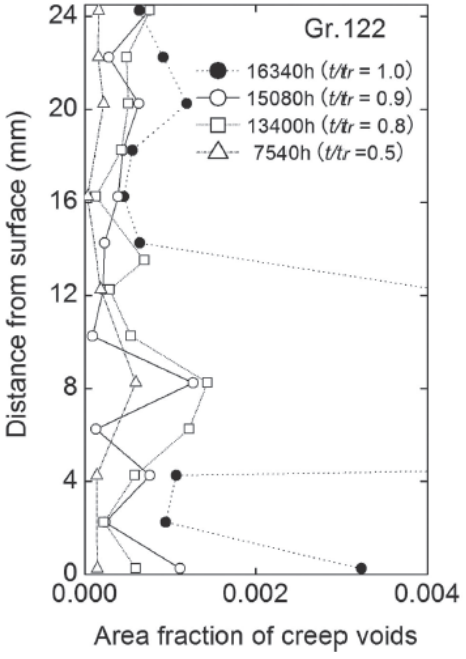

Fig. 17 Distributions of area fraction of creep voids along thickness direction in $\mathrm{HAZ}^{2}$.

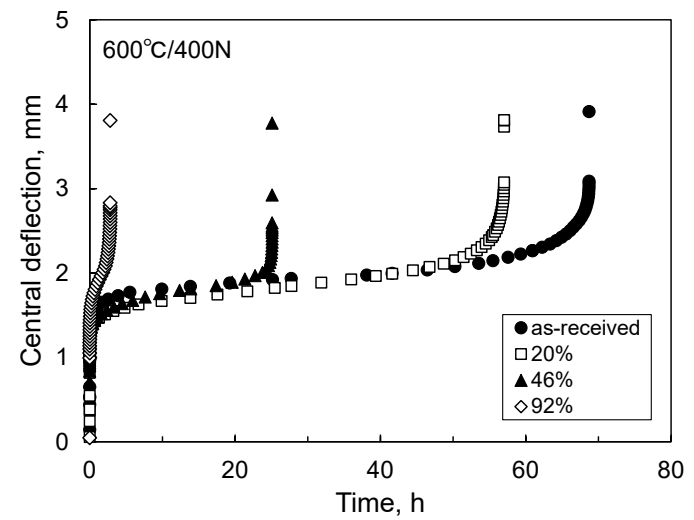

Fig. 18 Small punch curves measure at $600^{\circ} \mathrm{C} / 400 \mathrm{~N}$.

加しているのがわかる.46\%損傷材になると,距離 $10 \mathrm{~mm}$ 以上での $C_{\mathrm{H}}$ は $20 \%$ 中断材とほぼ同等であるが， $5.5 \mathrm{~mm}$ 付近におけるそれは 5.3 mass ppm と他の位置に比べ高い さらに，破断直前の寿命比 $92 \%$ にると，他の位置での $C_{\mathrm{H}}$ も大きく増加しているが， $5.5 \mathrm{~mm}$ 付近におけるその 増加がより顕著であり，その值は 8.3 mass ppm 程度まで 大きくなっている. 他の損傷材と直接比較はできないも のの，内表面側に近い $82 \%$ 損傷材の $C_{\mathrm{H}}$ も受取りまま材 に比べ増加しており，特に $20 \mathrm{~mm}$ 付近では 7.4 mass ppm と大きく増えている. なお，水素昇温脱離分析用試料を 採取した位置とは反対側の継手部ではあるが，82\%中断 材の $C_{\mathrm{H}}$ が高かった籄所（外表面から $15 \sim 25 \mathrm{~mm}$ 程度の 距離）にてボイド面積率が増加していることが観察され た ${ }^{2)}$.SEM 観察では，46\%損傷材で HAZ にボイドが僅 かに観察されたのみであったが 2), $C_{\mathrm{H}}$ は 46\%損傷材では 受取りまま材に比べて約 2 倍に増加した.このことから， $C_{\mathrm{H}}$ 計測は SEM 観察よりも感度良くクリープ損傷を検出 できると考えられる. Fig. 14 は， $C_{\mathrm{H}}$ を寿命比に対して外 表面からの距離ごとにプロットしたものである.いずれ の位置においても $C_{\mathrm{H}}$ は寿命消費に伴い単調に増加する
傾向にあり $5.5 \mathrm{~mm}$ 付近ではそれがより顕著である。ま た，寿命比が $20 \%$ では表面からの距離による $C_{\mathrm{H}}$ の差異 はあまり大きくないが，46\%になると外表面からの距離 に大きく依存するようになり，寿命末期の $92 \%$ 達する と $5.5 \mathrm{~mm}$ 付近と最小值を示寸 $13 \mathrm{~mm}$ 付近で 2 倍程度の 差になる．得られた結果は，20\%といった寿命初期では 板厚内で比較的均一に損傷が進行するのに対して，それ 以降では $5.5 \mathrm{~mm}$ 付近といった表面より少し内部に入っ たところで損傷が優先的に蓄積していくことを示唆し ている.

水素放出量 $C_{\mathrm{H}}$ とビッカース硬さの関係を示したもの が Fig. 15 である. 硬さの值として, 水素昇温脱離分析用 試料を採取した箇所と同じ外表面からの距離で溶融境 界から HAZ にかけての $2.5 \mathrm{~mm}$ の間の 10 点の平均值を 用いた。同図からわかるように，両者の間には明瞭な相 関は認められない，これは，水素放出特性変化が反映し ているものが軟化すなわちミクロ組織変化に起因した 材質劣化ではないことを示唆している. 本研究で用いた ものと同一のクリープ中断材で得られているボイド面 積率2)に対して水素放出量 $C_{\mathrm{H}}$ をプロットしたものを Fig. 16 亿示寸. 水素昇温脱離分析用試料を採取した箇所とボ イド面積率を測定した位置は必ずしも一致していなか ったため，報告されている Fig. 172)のデー夕間を結ぶ直 線上の值を読み取りそれをその位置でのボイド面積率 とみなした．同図からわかるように，一点大きく外れて いる点はあるものの, ボイド面積率の増加とともに $C_{\mathrm{H}}$ も増える傾向にあり，両者の間に比較的良好な関係が認 められる。この結果は，ボイドに代表されるようなクリ 一プ損傷を本手法が検出していることを支持している.

\section{$3 \cdot 4$ 損傷箇所のスモールパンチクリープ試験特性}

$3 \cdot 3$ 節で述べたように, 外表面から $5.5 \mathrm{~mm}$ 程度内部 に入ったところでクリープ損傷が優先的に生じている ことが示唆された。 そこで，当該箇所のクリープ特性を 直接計測・評価することを目的として，スモールパンチ クリープ試験を実施した。試験は, 通常の直径 $8 \mathrm{~mm} の$ 微小ディスク試験片の代わりに長方形状試験片を用い る改良スモールパンチ試験法 13), 14) とした. 通常の試験と の主な相違点は，下部ダイ穴が $6 \times 6 \mathrm{~mm}$ の正方形である というだけで，ボール径など他の条件は同じである。ま た, 試験片としては, 水素昇温脱離分析に供した後の長 方形状試験片（Fig. 3）を分析後に鏡面研磨しそのまま用 いた。 なお，水素チャージとその後の分析中の加熱はス モールパンチクリープ試験特性にほとんど影響を及ぼ さないことをあらかじめ確認している、スモールパンチ クリープ試験は, 温度 $600^{\circ} \mathrm{C}$, 荷重 $400 \mathrm{~N}$ の条件のもと, 高純度 $\mathrm{Ar}$ ガス雰囲気中にて実施した。

外表面下 $5.5 \mathrm{~mm}$ 近傍の試料で計測されたスモールパ ンチクリープ曲線(時間一変位曲線)を示したものが Fig. 18 である. 短時間試験の結果ではあるが，損傷度に応じ て破断寿命が異なり, 受取りまま材の破断寿命が $70 \mathrm{~h}$ 程 度であるのに対して $92 \%$ 損傷材のそれは $3 \mathrm{~h}$ 程度と $1 / 20$ 
程度に減少している. 破断試験片を観察したところ, こ れまでの報告 13),14) と同様, 損傷度によらず破壊はすべて 母材寄りの HAZ (FGHAZ や ICHAZ に相当する領域) で生じていた. 各損傷材で計測された破断寿命を線形損 傷則（時間消費則）に基づき整理した結果を Fig. 19 に示 す. クリープ中断時間の破断時間に対する寿命比 0.2 , 0.46, 0.92 を損傷度 $D_{\mathrm{C}}$, 受取りまま材のスモールパンチ クリープ破断寿命に対する損傷材の破断寿命の比を $D_{\mathrm{SP}}$ とし, 両者の和 $\left(D_{\mathrm{C}}+D_{\mathrm{SP}}\right)$ を表したものが同図の縦軸で ある. $46 \%$ 損傷材の值が幾分低いものの損傷和はほぼ 1 程度になっており, 線形損傷則が成り立つことが示唆さ れた. 得られた結果は, 外表面下 $5.5 \mathrm{~mm}$ 近傍の試料で 計測された $C_{\mathrm{H}}$ が寿命消費とともにほぼ線形的に増加す るという結果（Fig. 14）と整合しており，クリープ損傷 の程度が水素放出特性 $\left(C_{\mathrm{H}}\right)$ の変化に反映されているこ とを改めて確認することができた.

限られたクリープ試験条件下のデータのみではある が，今回得られた知見は水素昇温脱離分析法が Type IV 損傷の検出技術として有望であることを示唆している. 今後, さらに広範囲な試験条件下における水素放出特性 の変化を調べるとともに, 損傷（欠陥）の水素捕獲機構 をより一層明確にすることによって, 本手法を高 $\mathrm{Cr}$ フ エライト系耐熱鋼溶接継手部のクリープ損傷評価法と して確立できるものと期待している.

\section{4 結 言}

本研究では, Gr.122 鋼溶接継手の Type IV 損傷評価への 水素昇温脱離分析法の適用性について詳細に検討した. 具体的には, 損傷度の異なる複数のクリープ中断材を対 象に, 外表面からの距離が種々異なる箇所より採取した 微小サンプルの水素放出曲線を測定し, 板厚方向の水素 放出特性の分布を調べた. また, 水素放出特性変化の機序 解明の一環として, HAZ のみならず, HAZ 内の局所領域 の水素放出特性の測定も試みた. さらには, 水素放出特性 変化と硬さやボイド面積率, スモールパンチクリープ試 験結果との関係についても調査した，得られた知見をま とめて以下に示す.

(1) 溶接継手の水素放出特性はクリープによって大きく 変化するが，これは母材や溶接金属というより HAZ での水素放出特性の変化すなわち損傷の発生・蓄積を 主として反映していた。また，それは特に FGHAZや ICHAZ の HAZ 母材側でより顕著であった.

(2) 分析中に放出される水素量 $\left(C_{\mathrm{H}}\right)$ はクリープ寿命消費 ともに増加するが，特に外表面下 $5.5 \mathrm{~mm}$ と $20 \mathrm{~mm}$ 付 近での増加が著しく, 当該箇所における損傷の優先的 蓄積が示唆された. また, $C_{\mathrm{H}}$ と硬さの間には明瞭な関 係は認められないが，ボイド面積率によって $C_{\mathrm{H}}$ を良 好に整理することができた.

(3) 損傷が優先的に蓄積されていることが示唆された外 表面下 $5.5 \mathrm{~mm}$ 近傍のクリープ特性を直接計測・評価 することを目的として，改良スモールパンチクリープ 試験を実施した．その結果，損傷度とともに破断寿命

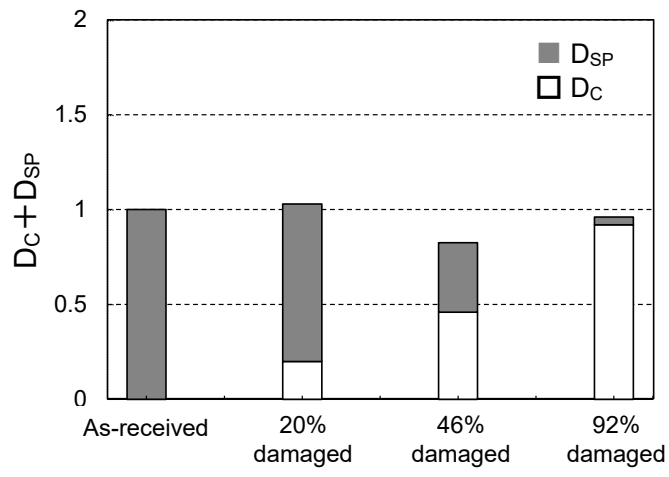

Fig. 19 Applicability of cumulative damage model to remaining-life assessment.

が線形的に減少し, クリープ損傷の程度が水素放出特 性 $\left(C_{\mathrm{H}}\right)$ の変化に反映されていることを改めて確認す ることができた.

本研究の一部は, 一般社団法人日本ボイラ協会のボイ ラー・圧力容器等研究助成の支援を受けた. ここに記して 謝意を表する.

\section{参 考 文 献}

1) F. Masuyama, "Creep degradation in welds of Mod.9Cr-1Mo steel", International Journal of Pressure Vessels and Piping, Vol. 83, pp. 819-825 (2006).

2) H. Hongo, M. Tabuchi and T. Watanabe, "Evaluation of creep strength and damage of Gr.122 steel weld joint", Journal of the Society of Materials Science, Japan, Vol.60, No.2, pp.116-123 (2011).

3) Y. Hasegawa, T. Muraki and M. Ohgami, "Identification and formation mechanism of a deformation process determining microstructure of type-IV creep damaged of the advanced high $\mathrm{Cr}$ containing ferritic heat resistant steel", Tetsu-toHagane, Vol.90, pp. 609-617 (2004).

4) T. Watanabe, M. Yamazaki, H. Hongo, M. Tabuchi and T. Tanabe, "Relationship between Type IV fracture and microstructure on $9 \mathrm{Cr}-1 \mathrm{Mo}-\mathrm{V}-\mathrm{Nb}$ steel welded joint creep-rupture after long term", Tetsuto-Hagané, Vol.90, pp.206-212 (2004).

5) H. Yamashita, S. Komazaki and M. Oshima, "Creep damage evaluation of Gr.122 steel welded joint by hydrogen thermal desorption analysis", Journal of the Society of Materials Science, Vol. 65, pp.300-305 (2016).

6) T. Ohtani, T. Honma, Y. Ishii, M. Tabuchi, H. Hongo and M. Hirao, "Evolutions of nonlinear acoustics and microstructural change during creep in Gr.122 steel welded joint", Journal of the Society of Materials Science, Vol.64, No.2, pp.80-87 (2015).

7) M. Nagumo, "State of hydrogen in materials II", Zairyo-to-Kankyo, Vol. 54, No.6, pp. 251-261 (2005).

8) J. P. Hirth, "Effects of hydrogen on the properties of iron and steel", Metallurgical and Materials 
Transactions A, Vol. 11, pp. 861-890 (1980).

9) H. G. Lee and J. Y. Lee, "Hydrogen trapping by TiC particles in iron”, Acta Metall., Vol. 32, pp. 131-136 (1984).

10) K. Takai, "Hydrogen existing states in metals", Transactions of the Japan Society of Mechanical Engineers A, Vol. 70, pp. 1027-1035 (2004).

11) S. Komazaki, T. Honda, T. Sakamura, K. Sawada, K. Kimura and Y. Kohno, "Change in hydrogen desorption characteristics of Mod.9Cr-1Mo steel due to creep", Tetsu-to-Hagané, Vol. 96, pp. 614-619 (2010).

12) H. Yamashita, S. Komazaki, M. Yonemura and M. Igarashi, "Creep remaining-life prediction of Gr.91 steel based on change in hydrogen desorption characteristics", Proceedings of the 49th Symposium on Strength of Materials at High Temperatures, The Committee on High Temperature Strength of Materials, The Society of Materials Science, Japan, pp.111-115 (2011).

13) S. Komazaki, Y. Konishi, A. Kanaya, H. Watanabe and J. Kusumoto, "Creep deformation and fracture behaviors of high $\mathrm{Cr}$ ferritic steel by rectangular SP specimens", Journal of the Society of Materials Science Japan, Vol. 60, pp. 139-145 (2011).

14) S. Komazaki, H. Uchimura, H. Yamashita, J. Kusumoto, and Y. Tabuchi, "Creep property evaluation of $12 \% \mathrm{Cr}$ ferritic steel welded joint by modified small punch creep test", Journal of the Society of Materials Science Japan, Vol. 65, pp. 306312 (2016). 